\title{
Boşluklu Betonun Darbe Yükü Altındaki Davranışının Mezoskopik Analizi
}

\author{
Ayda Şafak AĞAR ÖZBEK ${ }^{1}$ \\ Ronnie Refstrup PEDERSEN ${ }^{2}$ \\ Jaap WEERHEIJM ${ }^{3}$
}

\section{ÖZ}

Boşluklu beton, yüksek miktarda mezo-boyutta hava boşluğu içeren özel bir tip betondur. İçerdiği boşluklar nedeniyle boşluklu betonun mekanik özellikleri normal betonlardan oldukça farklıdır. Bu nümerik çalışmanın amacı, boşluklu betonun dinamik yük altındaki davranışının mezoskopik olarak analiz edilmesidir. Gerçekleştirilen sonlu eleman analizlerinde, açık direkt entegrasyon (explicit direct integration) yöntemi kullanılmıştır. Betonun çimento bazlı fazlarının tanımlanmasında Beton Hasar Plastisite Modeli kullanılmıştır. Boşluklu betonun dört fazlı bir malzeme olarak gerçeğe yakın bir şekilde temsil edilebilmesi için her bir fazın ayrı bir şekilde tanımlanabildiği bir sonlu eleman ağı geliştirme programı oluşturulmuştur. Boşlukların etkilerinin daha iyi araştırılabilmesi için dairesel boşluklar içeren yalın betonlar şeklinde tanımlanmış model boşluklu betonlar ayrıca incelenmiştir. Gerçek boşluklu betonların nümerik incelemeleri ile elde edilen sonuçlar, gerek darbe dayanımı gerekse çatlak dağılımı yönünden deneysel sonuçlarla uyum göstermektedir.

Anahtar Kelimeler: Açık zaman hesabı, mezoskopik analiz, boşluklu beton, beton hasar plastisite modeli.

\section{ABSTRACT \\ Mesoscopic Analysis of the Behavior of Porous Concrete under Impact Loading}

Porous concrete is a special type of cementitious material incorporating a high amount of meso-sized air pores that makes its mechanical characteristics markedly different from normal concrete. The objective of this numerical study is mesoscopically analyzing the behavior of porous concrete under dynamic loading. In the finite element analyses, explicit

Not: Bu yaz1

- Yayın Kurulu'na 30.03.2015 günü ulaşmıştır.

- 30 Haziran 2017 gününe kadar tartışmaya açıktır.

1 İstanbul Teknik Üniversitesi, İnşaat Mühendisliği Bölümü, İstanbul - sagar@itu.edu.tr

2 Rambøll Offshore Wind, Esbjerg, Danimarka - rrp@ramboll.com

Aalborg Üniversitesi, Esbjerg Teknoloji Enstitüsü, Esbjerg, Danimarka - rrp@civil.aau.dk

3 Delft Teknoloji Üni., İnşaat Müh. ve Yer Bil. Fakültesi, Delft, Hollanda - j.weerheijm@tudelft.nl,

TNO Defense, Safety and Security, Rijswijk, Hollanda - jaap.weerheijm@tno.nl 
direct integration method was adopted. Concrete Damage Plasticity Model was selected to define the material properties of the cementitious phases. With the aim of realistically representing porous concrete as a four-phase material, a mesh generation program was developed where each phase was separately defined. In order to better investigate the effects of the properties of pores, model porous concretes were also analyzed in the form of plain concrete meshes incorporating circular pores. The numerical analysis results of real concrete mixtures were in good agreement with the experimental results both in terms of quantifying the impact strength as well as demonstrating a realistic crack pattern formation for the porous concretes that have been analyzed.

Keywords: Explicit time integration, mesoscopical analysis, porous concrete, concrete damaged plasticity

\section{GİRIŞ}

Boşluklu beton, özellikle geçirgen niteliği sayesinde birçok değişik uygulama alanında kullanılmaktadır ve araştırılmaktadır [1,2]. İçerdiği yüksek miktarda mezo-boyutta boşluklar nedeniyle normal betonla karşılaştırıldığında daha düşük statik dayanımlara ulaşabilirken dinamik yükleme altındaki davranışı da normal betona göre oldukça farklıdır. Boşluklu yapısı ve agrega dağılımı, boşluklu betonun yükleme altında çoklu çatlaklar oluşturabilen bir malzeme olmasını sağlamaktadır. Bu özellikleri sayesinde boşluklu betonlar, önemli yapıların koruyucu dış duvarları ve patlayıcı depolarının inşasında kullanılmak üzere, darbe yükü altında çok sayıda çevre için tehlike oluşturmayacak küçük boyutta fragmana ayrılan çimento bazlı bir malzemenin geliştirilmesi ve modellenmesini hedefleyen bir araştırma projesi dahilinde incelenmiştir. Proje kapsamında değişik tipte boşluklu betonlar üretilmiş, statik ve dinamik yüklemeler altında test edilmiştir. Deneysel çalışma ile beraber, boşluklu betonun dinamik davranışını etkileyen parametreler nümerik olarak da incelenmiş̧ir. Bu çalışma, dinamik incelemelerde kullanılan yöntemleri ve elde edilen sonuçlardan seçilen bazı çıkarımları özetlemektedir.

Boşluklu beton ve normal betonların davranışlarının nümerik analizlerinde orataya çıkan başlıca farklılıklar, boşluklu betonlarda bulunan yüksek miktarda, rastgele şekil ve dağılıma sahip mezo-boyutta hava boşlukları ve boşlukların serbest yüzeylerinin yükleme sırasında oluşturduğu kontaktlar olarak belirtilebilir. Analizlerde, açık sonlu eleman çözüm yönteminin esas alındığı ABAQUS/Explicit kullanılmıştır. Boşluklu betonda bulunan çimento bazlı fazların (çimento hamuru-agrega arafazı ve çimento hamuru) tanımlanması için Beton Hasar Plastisite (Concrete Damaged Plasticity) modeli kullanılmıştır. Beton Hasar Plastisite modeli, Lubliner ve diğerleri tarfindan geliştirilmiş, Lee ve Fenves tarafından modifiye edilmiş, çimento bazlı malzemelerin tanımlanmasında yaygın bir şekilde tercih edilen bir malzeme modelidir [3-5]. Modelde, iki ana mekanizma temel alınmıştı; bunlar çekme çatlaması (tensile cracking) ve basınç ezilmesi (compressive crushing) olarak modelde belirtilmiştir. Oluşan hasarın tanımlanması ise çekme ve basınçta tanımlanan iki farklı rijitlik degradasyonu ile gerçekleştirilmektedir. Modelde yükleme hızı hassasiyeti mevcuttur, bu nedenle şekil değiştirme hızı arttırımı ile tepe noktası artışı tespit edilebilmektedir [6-8].

Boşluğun oluşturduğu gerilme konsantrasyonları ve hasar, tek boşluk için incelendiğinde, çok sayıda boşluk içeren bir malzemede yarattı̆̆ 1 etki de daha iyi anlaşılabilmektedir. 
Timoshenko and Goodier'nin elastisite teorisine dayalı, çekme (veya basınç) yüklemesi altındaki sonsuz genişlikte plakadaki elastik gerilme dağılımı hesabı (Şekil 1) aşağıdaki denklemlerle özetlenebilir $[9,10]$.

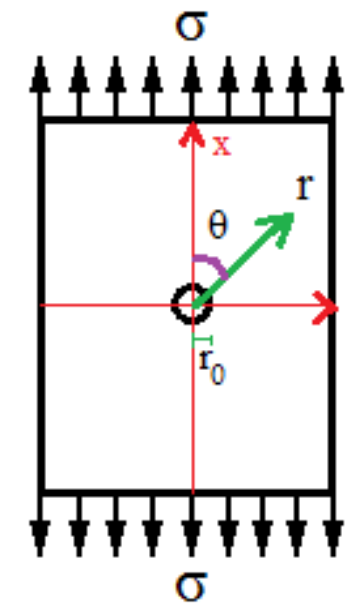

Şekil 1. Tek dairesel boşluk içeren sonsuz genişlikte elastik plaka [10]

$\sigma_{r r}=\frac{\sigma}{2}\left[1-\frac{r_{0}^{2}}{r^{2}}+\left(1+3 \frac{r_{0}^{4}}{r^{4}}-4 \frac{r_{0}^{2}}{r^{2}}\right) \cos 2 \theta\right]$

$\sigma_{\theta \theta}=\frac{\sigma}{2}\left[1+\frac{r_{0}^{2}}{r^{2}}-\left(1+3 \frac{r_{0}^{4}}{r^{4}}\right) \cos 2 \theta\right]$

$\sigma_{r \theta}=-\frac{\sigma}{2}\left(1-3 \frac{r_{0}^{4}}{r^{4}}+2 \frac{r_{0}^{2}}{r^{2}}\right) \sin 2 \theta$

Dairesel boşluğun sınırında $\left(r=r_{0}\right)$ denklemler aşağıdaki gibi sadeleşmektedir $\left(\sigma_{\mathrm{rr}}\right.$ ve $\sigma_{\mathrm{r} \theta}$ bulunmamaktadır):

$\sigma_{\theta \theta}=\sigma_{0}(1-2 \cos 2 \theta)$

$\left(\sigma_{\theta \theta}, \theta= \pm \pi / 2\right.$ 'de $3 \sigma, \theta=0$ ve $\pi$ 'de $-\sigma^{\prime}$ dır. Gerilme konsantrasyon faktörü ise sırasıyla 3 ve 1 'dir.) $\mathrm{Bu}$ durum hem çekme hem de basınç yükmelemeleri için geçerlidir. Nümerik analizlerin başlangıcında da tek boşluk içeren plakaların statik basınç yüklemesi altındaki davranışı incelenmiş, boşluğun neden olduğu gerilme konsantrasyonları hesaplanarak yukarıdaki analitik sonuçlarla karşılaştırılmıştır.

\section{SAYISAL İNCELEMELER}

Boşluklu betonun dinamik davranışının araştırılması için sonlu eleman analizleri gerçekleştirilmiştir. Çalışmanın başlıca amacı, boşluklu betonların darbe yükü altındaki 
Boşluklu Betonun Darbe Yükü Altındaki Davranışının Mezoskopik Analizi

davranışının gerçekçi bir şekilde temsil edilerek değerlendirilmesidir. Bunun yanında, boşlukların malzemenin davranışı üzerindeki etkisini ayrıca inceleyebilmek için model boşluklu betonlar incelenmiştir. Gerçek boşluklu betonlarda pek çok parametre birbiri ile bağlantılı olarak etkidiği için sadece boşlukların etkisini incelemek mümkün olamamaktadır. Bu çalışmada, sayısal incelemelerde kullanılan yöntemler ve seçilmiş bazı sonuçlar sunulmaktadır.

Analizlerde boşluklu beton, agregalar, arafaz, çimento hamuru ve mezo-boyutta rastgele şekilli boşluklardan oluşan dört fazlı bir malzeme olarak modellenmiştir. Sonlu eleman ağının, deneysel olarak üretilmiş boşluklu betonları gerçekçi bir şekilde temsil edebilmesi için sayısal incelemeler, boşluklu betonun çok büyük bir kısmını oluşturan iri agregaların şekillerinin ve dağılımının tespit edilmesi ile başlamaktadır. Farklı karışımlarda bulunan agregaların gerçek şekilleri ve dağılımları üç boyutlu bilgisayarlı tomografi (BT) ile belirlenmiştir. MATLAB programı kullanılarak, bu verileri temel alan, gerçeğe olabildiğince yakın, rastgele şekilli ve dağılımlı boşluklar içeren boşluklu beton ağları oluşturabilen bir program geliştirilmiştir. Programda, agregaların sınır koordinatları belirlendikten sonra, her bir agreganın etrafında dört fazı (agrega, arafaz, çimento hamuru ve hava) birbirinden ayıran sınır eğrileri tanımlanmaktadır. Numunenin bütünü ve yakından gösterilen bir parçasında oluşturulan faz sınırları Şekil 2'de gösterilmektedir. Daha sonra oluşturulan arka plan ağının önce düğüm noktaları ardından da elemanları hangi sınırın içinde kaldıklarına göre sınıflandırılmış, hava fazına ait eleman ve düğüm noktaları ağdan çıkarılarak kalan elemanlar tekrar düzenlenmiştir. Analizlerde, aksisimetrik geometri kullanılmış, $110 \mathrm{~mm}$ çapında, $220 \mathrm{~mm}$ yüksekliğinde silindrik çelik ağırlığın, serbest düşmeli darbe testinde de olduğu gibi $4.5 \mathrm{~m} / \mathrm{s}$ çarpma hızı ile beton numuneye çarpması incelenmiştir. Analizlerde, deney düzeneğine benzer şekilde beton numune, çelik tabla üzerine yerleştirilmiştir. Kullanılan sonlu eleman ağlarından bir örnek Şekil 3'de verilmiştir.

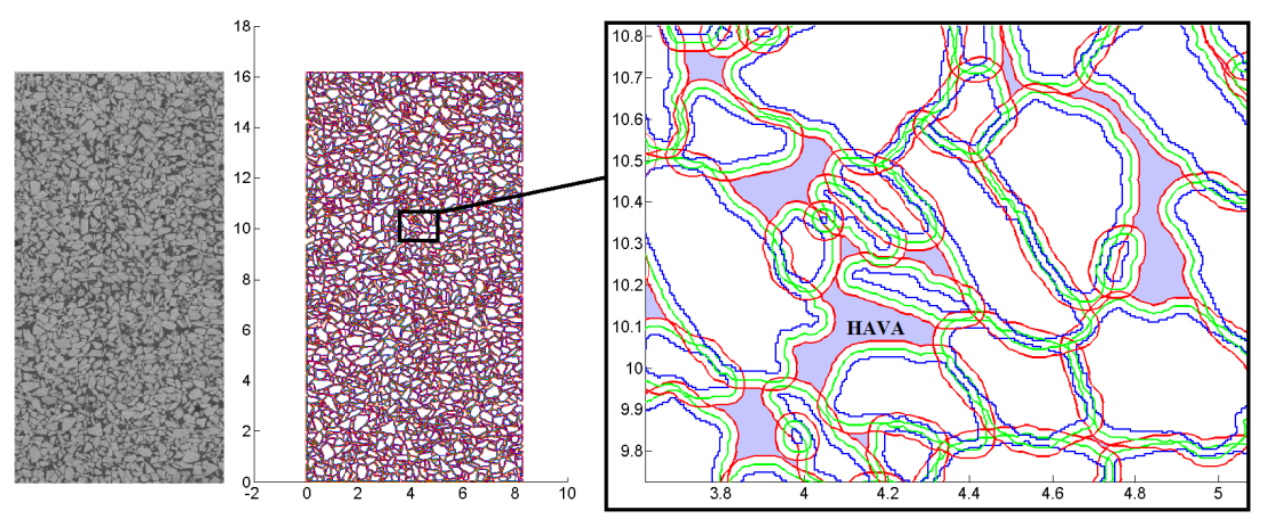

Şekil 2. Boşluklu betonda bulunan farklı fazların sınırlarının ăg gelişstirme programı tarafindan oluşturulması 


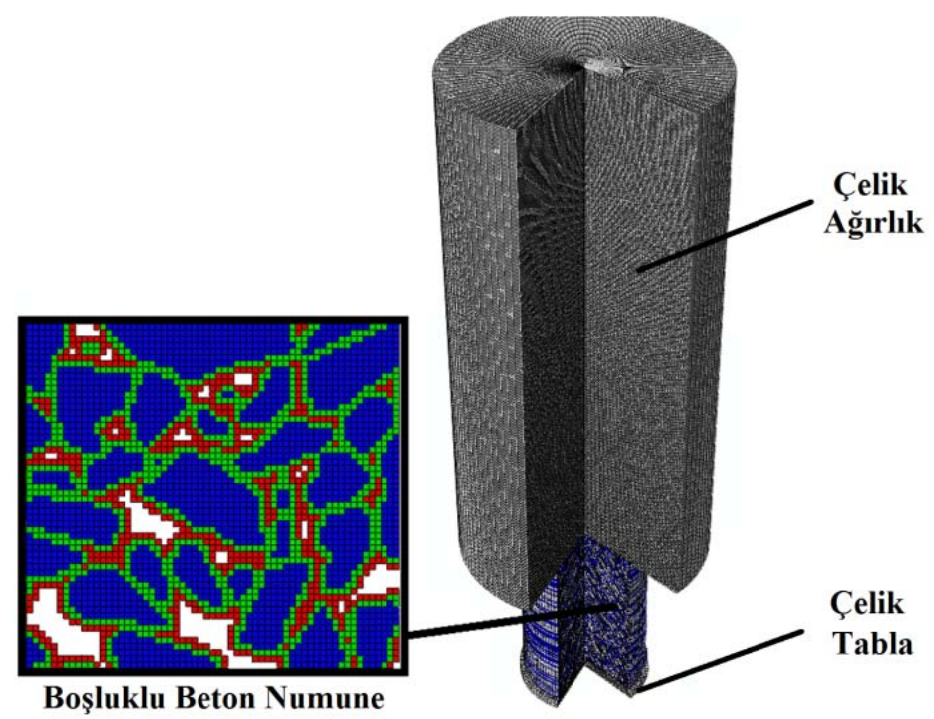

Şekil 3. Numune ve darbe deneyi düzeneğini temsil eden bir sonlu eleman ağı örneği

\begin{abstract}
Agregalar elastik olarak tanımlanırken, çimento bazlı fazlar (arafaz "ITZ" ve çimento hamuru) Beton Hasar Plastisite modeli kullanılarak tanımlanmıştır. Beton Hasar Plastisite modelinin tanımlanabilmesi için gerekli olan veriler, çimento bazlı fazların deneysel gerilme-şekil değiştirme verileri (elastik limitin dışında kalan bölge) kullanılarak oluşturulabilmektedir. Sonlu eleman programı, inelastik şekil değiştirme değerlerini plastik şekil değiştirmeye çevirerek hesaplama yaptığ için, elde edilen plastik şekil değiştirme değerlerinin negatif veya artan inelastik şekil değiştirme ile azalan yönde değişen bir özellik göstermemesi için deneysel veriler aşağıdaki denklemler de kullanılarak kontrol edilmeli ve gerekirse bu formata uygun şekilde modifiye edilmelidir. Modelde esas alınan elastik ve inelastik şekil değiștirme değerleri arasındaki bağıntı Şekil 4'te de görülmektedir; şekilde pl ve in sırasıyla plastik ve inelastik için (basınç durumunda) kullanılan kısaltmalardır. Benzer bir şekilde, çekme altında inelastik şekil değiştirme ck kısaltması ile gösterilmektedir. Veri olarak temin edilmesi gereken inelastik şekil değiştirme değerleri, tek eksenli gerilme altında deneylerden elde edilen toplam şekil değiştirmeden hasar görmemiş malzemeden elde edilen elastik şekil değiştirme çıkartılarak elde edilir. Aynı işlem hem basınç hem de çekme deneyi verilerine uygulanır. Sonuç olarak sonlu elemanlar programında, betonda bulunan çimento bazlı fazların hasar görmemiş hallerinin rijitlik bilgileri ve deneysel gerilme-inelastik şekil değiştirme verileri kullanılarak, tek eksenli çekme veya basınç gerilme-plastik şekil değiştirme bağıntısı tanımlanır. Denklemlerde $\varepsilon c^{\sim p l}, \varepsilon t^{\sim \mathrm{pl}}, \varepsilon c^{\sim i n}, \varepsilon t^{\sim i n}$ sirasıyla plastik basınç şekil değiştirmesi, plastik çekme şekil değiştirmesi, inelastik basınç şekil değiştirmesi and inelastik çekme şekil değiştirmesidir. $E_{0}$ ilk (hasarsız) rijitlik, $d_{t}$ ve $d_{c}$ ise sırasıyla çekme ve basınç hasar değişkenlerini göstermektedir.
\end{abstract}

$\tilde{\varepsilon}_{C}^{p l}=\tilde{\varepsilon}_{C}{ }^{i n}-\frac{d_{C}}{\left(1-d_{C}\right)} \frac{\sigma_{C}}{E_{0}} \quad$ (basınç altında) 


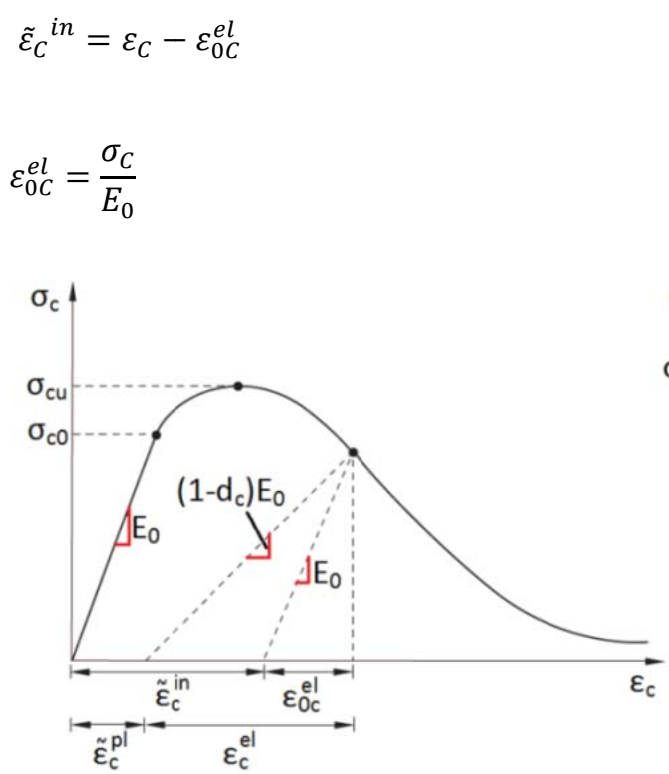

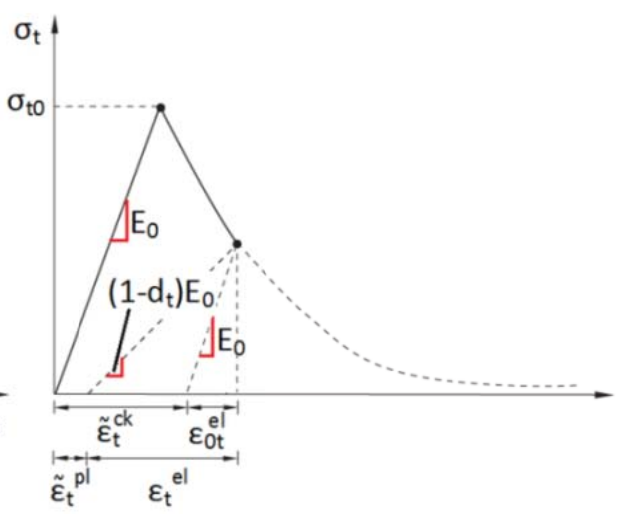

Şekil 4. Beton Hasar Plastisite modelinde basınç ve çekme davranışları [7]

Modelde hasar, bir elemanın rijitliğinde oluşan azalma olarak tanımlanmaktadır ve izotropik kabul edilmektedir. Skaler bir değişken olan hasarın tanımında 0 tamamen hasarsız, 1 ise tamamen hasarlı durumu göstermektedir. Çimento bazlı malzemelerin ve fazların çekme ve basınç altındaki davranışı farklı olup, modelde de iki ayrı veri grubuyla tanımlandığından, çekme ve basınç için iki farklı hasar değişkeni tanımlanmaktadır. Daha önceki denklemlerdeki bağıntıları farklı şekilde ifade edersek hasar değişkenlerinin malzemenin rijitliğini ne şekilde değiştirdiği daha açık bir şekilde görülebilir. Sonraki bölümlerde bulunan, elemanlar için hasar konturlarını gösteren grafiklerde çekme ve basınç hasarları, sırasıyla DamageT ve DamageC olarak gösterilmektedir.

$\sigma c=E_{0}(1-d c)\left(\varepsilon c-\tilde{\varepsilon}_{c}^{p l}\right)$

$\sigma t=E_{0}(1-d t)\left(\varepsilon t-\tilde{\varepsilon}_{t}^{p l}\right)$

Modelde kullanılan çimeto bazlı fazlardan arafazın (ITZ fazının) mekanik özellikleri ile ilgili veri (Şekil 5), tek eksenli çekme deneylerinden elde edilen sonuçların [11] tepe değerleri korunarak, Jankoviak and Lodygowski'nin yaygın bir şekilde referans alınan yayını ve Beton Hasar Plastisite modelini tanımlarken yukarıda belirtilen denklemler referans alınarak oluşturulmuştur [6,7]. Deneysel verinin direkt olarak kullanılması yerine bu şekilde düzenlenmesi, yukarıda belirtilen şekil değiştirme verisi hatasının oluşmasını engellemek içindir. Benzer bir yaklaşım yine deneysel sonuçlardan faydalanarak oluşturulmuş çimento hamuru verilerinde de kullanılmıştır. Çimento hamurunu tanımlarken 
basınç dayanımı $100 \mathrm{MPa}$, çekme dayanımı ise $2.8 \mathrm{MPa}$ olarak alınmıştır. Malzemeyi oluşturan fazların yükleme hızına bağlı davranışı modele veri olarak sağlanan viskozite parametreleri ile tanımlanmaktadır. Boşluklu betonda bulunan fazlardan agrega elastik olarak tanımlanmış, çimento bazlı fazlar için kullanılan viskozite parametresi ise yine Jankowiak and Lodygowski'nin eserinden alınmıştır [6].
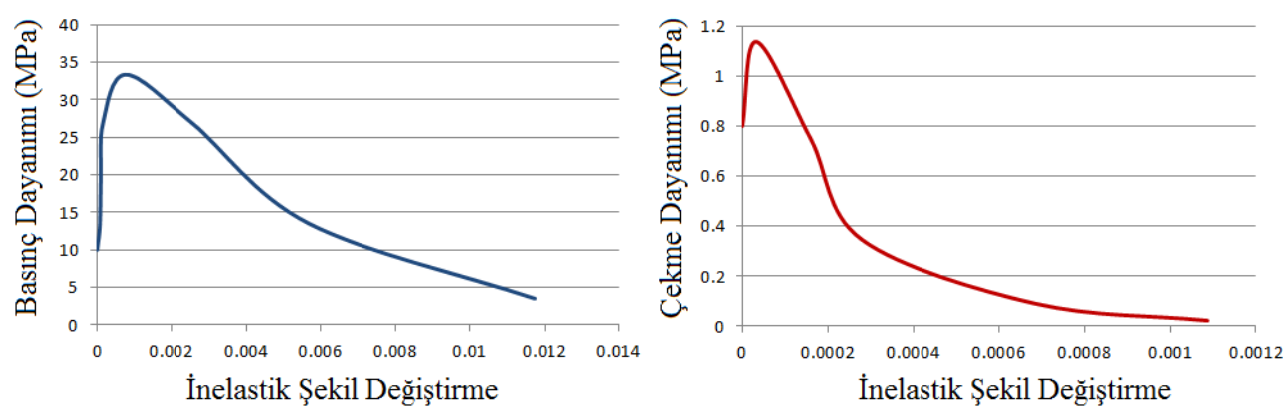

Şekil 5. Arafaz (ITZ fazı) için basınç ve çekme dayanımı-inelastik şekil değiştirme grafikleri

Analizlerde, sonlu eleman analizi programı ABAQUS/Explicit kullanılmıştır. Açık (explicit) sonlu eleman yöntemi, kapalı (implicit) yöntemlere bir alternatif olarak dinamik nonlineer analizlerde kullanılmak için oluşturulmuştur. Açı çözüm, büyük deformasyon ve dönmelerin söz konusu olduğu, yüksek nonlineeriteye sahip, çok kısa süreli yükleme durumlarında tercih edilen bir yöntem olmuştur [12-15]. Açık zaman entegrasyon yöntemi artıml, fakat yinelemeli (iteratif) olmayan bir çözüm şeklidir.

Açık zaman entegrasyon tekniklerinden en yaygın şekilde kullanılanı merkezi farklar metodudur. Metodun özellikleri, genel hareket denkleminden de yola çıkarak aşağıdaki denklemlerle ve sonuca ne şekilde yaklaşıldığını gösteren Şekil 6 ile özetlenebilir [16,17].

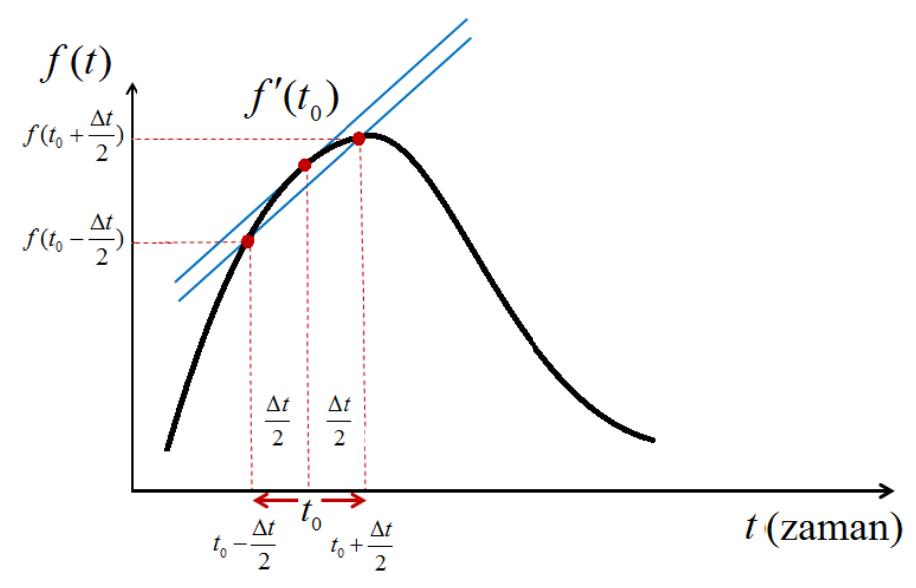

Şekil 6. Açık çözümde kullanılan merkezi farklar yönteminin şekilsel tanımı [16,17] 
Merkezi farklar metodu kullanılarak şekilde gösterilen fonksiyon için elde edilen denklemler aşağıdaki gibidir:

$\mathrm{f}^{\prime}\left(\mathrm{t}_{0}\right) \approx \frac{\mathrm{f}\left(\mathrm{t}_{0}+\frac{\Delta \mathrm{t}}{2}\right)-\mathrm{f}\left(\mathrm{t}_{0}-\frac{\Delta \mathrm{t}}{2}\right)}{\Delta \mathrm{t}} \approx \frac{\mathrm{f}\left(\mathrm{t}_{0}+\Delta \mathrm{t}\right)-\mathrm{f}\left(\mathrm{t}_{0}-\Delta \mathrm{t}\right)}{2 \Delta \mathrm{t}}$

$\mathrm{f}^{\prime \prime}\left(\mathrm{t}_{0}\right) \approx \frac{\mathrm{f}^{\prime}\left(\mathrm{t}_{0}+\frac{\Delta \mathrm{t}}{2}\right)-\mathrm{f}^{\prime}\left(\mathrm{t}_{0}-\frac{\Delta \mathrm{t}}{2}\right)}{\Delta \mathrm{t}} \approx \frac{\mathrm{f}\left(\mathrm{t}_{0}+\Delta \mathrm{t}\right)+\mathrm{f}\left(\mathrm{t}_{0}-\Delta \mathrm{t}\right)-2 \mathrm{f}\left(\mathrm{t}_{0}\right)}{(\Delta \mathrm{t})^{2}}$

Aynı kuralı, yer değiştirme ve dolayısıyla da genel hareket denklemine uygulayarak aşağıdaki ifadeler elde edilebilir. Denklemlerde sırasıyla $[\mathrm{M}],[\mathrm{C}],[\mathrm{K}]$ and $\{\mathrm{f}(\mathrm{t})\}$, kütle, sönümleme ve rijitlik matrislerini ve dış yükü göstermektedir.

$$
\begin{aligned}
& {[\mathrm{M}]\{\ddot{\mathrm{x}}(\mathrm{t})\}+[\mathrm{C}]\{\dot{\mathrm{x}}(\mathrm{t})\}+[\mathrm{K}]\{\mathrm{x}(\mathrm{t})\}=\{\mathrm{f}(\mathrm{t})\}} \\
& \dot{\mathrm{x}}(\mathrm{t}) \approx \frac{\mathrm{x}(\mathrm{t}+\Delta \mathrm{t})-\mathrm{x}(\mathrm{t}-\Delta \mathrm{t})}{2 \Delta \mathrm{t}} \\
& \ddot{x}(\mathrm{t}) \approx \frac{\mathrm{x}(\mathrm{t}+\Delta \mathrm{t})+\mathrm{x}(\mathrm{t}-\Delta \mathrm{t})-2 \mathrm{x}(\mathrm{t})}{(\Delta \mathrm{t})^{2}} \\
& {[M(t)] \frac{x(t+\Delta t)+x(t-\Delta t)-2 x(t)}{(\Delta t)^{2}}+[C(t)] \frac{x(t+\Delta t)-x(t-\Delta t)}{2 \Delta t}+[K(t)]\{x(t)\}} \\
& =\{\mathrm{f}(\mathrm{t})\}
\end{aligned}
$$

Denklem son olarak aşağıdaki şekli almaktadır:

$$
\begin{aligned}
& \left(\frac{[\mathrm{M}(\mathrm{t})]}{(\Delta \mathrm{t})^{2}}+\frac{[\mathrm{C}(\mathrm{t})]}{2 \Delta \mathrm{t}}\right) \underbrace{\boldsymbol{x}(\boldsymbol{t}+\Delta \boldsymbol{t})}_{\text {bilinmeyen }} \\
& =\{\mathrm{f}(\mathrm{t})\}-\left([\mathrm{K}(\mathrm{t})]-\frac{2[\mathrm{M}(\mathrm{t})]}{(\Delta \mathrm{t})^{2}}\right) \underbrace{\boldsymbol{x}(\boldsymbol{t})}_{\text {bilinen }}-\left(\frac{[\mathrm{M}(\mathrm{t})]}{(\Delta \mathrm{t})^{2}}-\frac{[\mathrm{C}(\mathrm{t})]}{2 \Delta \mathrm{t}}\right) \underbrace{\boldsymbol{x}(\boldsymbol{t}-\Delta \boldsymbol{t})}_{\text {bilinen }}
\end{aligned}
$$

Denklemde bilinen/bilinmeyen şeklinde belirtildiği gibi, açık dinamik analizde, yer değiştirmeler ve hızlar her bir zaman adımının başlangıcında zaten biliniyor olan değerler cinsinden hesaplanmaktadır. Son denklemde görüldüğü gibi, $(t+\Delta t)$ zamanındaki yer değiştirme, bir önceki zaman (t) adımındaki matrisler ve $(\mathrm{t}-\Delta \mathrm{t})$ ve t'deki yer değiştirmeler kullanılarak elde edilmektedir. Bunun yanında, bu yöntemde geometrik ve malzeme nonlineeritelerini hesaba katmak için matrisler her adımda güncellenmektedir. Matrisler her adımda tekrar hesaplanarak yenilense de çözümde iterasyon bulunmaması nedeniyle iki adım arasında matrislerde büyük farklar oluşmaması için zaman adımları çok küçük alınmalıdır. Şekil değiştirme, iteratif bir şekilde hesaplanmadığı için, açık hesap kapalı 
hesaba kıyasla daha kolay gerçekleştirilebilen bir çözüm sunmakla beraber, zaman adımlarının çok küçük tutulmasının hesabın şartlarından biri olması bu hesabı koşullu olarak stabil (conditionally stable) kılmaktadır. Stabilite sınırı (alınması mümkün olan en büyük zaman adımı) genel olarak denklem 8 'de belirtildiği gibi, bir gerilme dalgasının sonlu eleman ağında bulunan en küçük elemandan geçmesi için gerekli olan süre olarak kabul edilir.

$\Delta t \approx \frac{L_{\min }}{c_{d}}$

Eğer modelde tek bir malzeme tanımlanmışsa, ilk zaman adımı en küçük eleman boyutu $\left(\mathrm{L}_{\min }\right)$ kullanılarak hesaplanır. Eğer birden çok malzeme mevcutsa, zaman adımı hesabında en yüksek dalga hızı sağlayan malzeme esas alınır. $C_{d}$ söz konusu malzemedeki dalga hızını göstermektedir. Yeterince küçük zaman adımı tanımlanmaması durumu, çözümde instabiliteye neden olarak, şekil değiştirme vb. değişkenlerin zamana bağlı davranışlarında büyüklüğü gittikçe artan sapmalara neden olur. Açık hesabın önemli bir parçası olan toplam enerji dengesi de bu durumda korunamaz [7, 18-21]. İterasyonun bulunmamasının getirdiği küçük zaman adımı zorunluluğu açık hesabın, özellikle toplam yükleme süresi çok kısa olan darbe deneyi vb. gerilme dalgası yayılmasını temel alan durumların hesabında kullanılmasını mümkün kılmaktadır [3, 12, 13, 22].

Açık entegrasyon hesabı içeren yöntemlerde iterasyon bulunmadığı için enerji denge denklemi hesabı, yakınsanan sonucun kontrolü açısından gereklidir. Kullanılan enerji denge denklemi aşağıdaki gibi özetlenebilir:

$\mathrm{E}_{\mathrm{I}}+\mathrm{E}_{\mathrm{VD}}+\mathrm{E}_{\mathrm{FD}}+\mathrm{E}_{\mathrm{KE}}-\mathrm{E}_{\mathrm{W}}=\mathrm{E}_{\text {toplam }}$

Denklemde:

$E_{\mathrm{I}}$ : iç enerji (elastik, inelastik, "yapay" şekil değiştirme enerjileri)

$\mathrm{E}_{\mathrm{VD}}$ : viskoz enerji kayb1

$\mathrm{E}_{\mathrm{FD}}$ : sürtünme ile enerji kaybı

$\mathrm{E}_{\mathrm{KE}}$ : kinetik enerji

$\mathrm{E}_{\mathrm{W}}$ : dış yükten kaynaklanan iş

$\mathrm{E}_{\text {toplam: }}$ : sistemin toplam enerjisi

Açık çözüm yöntemleri kullanarak sonlu eleman analizi gerçekleştiren programlar (ABAQUS/Explicit gibi) yukarıda belirtilen enerji dengesi bileşenlerini her bir zaman adımında hem tüm sistem için hem de modelin parçaları için ayrı ayrı hesaplamaktadırlar. $\mathrm{Bu}$ değerlerin uygun şekilde kontrolü ve yorumlanması ise tamamen kullanıcıya aittir. Kontrol sırasında, kumsaati modunu engellerken ortaya çıkan "yapay" şekil değiştirme enerjisinin toplam iç enerjinin \% 1-2'sinden daha yüksek olması, kinetik enerjinin dış yükten kaynaklanan iş veya iç enerjinin \% 5-10'undan yüksek olması, toplam enerjide ani ve büyük artışlar vb. durumlarda alınması gereken çeşitli önlemler bulunmaktadır. Sistemin tamamının enerji bileşenlerini inceledikten sonra, kabul edilenden fazla enerji değişikliğine neden olabilecek her bir model parçası da ayrı ayrı incelenerek modelde çeşitli değişiklikler 
yapılmalıdır. Enerji kontrolleri yapılmadığı takdirde, modelle ilgili sorunlar bulunması durumunda bile çözüm yine de yakınsayabilecek ancak elde edilen sonuçlar gerçek çözüm değerinden uzaklaşacaktır.

Sayısal hesabın daha iyi açıklanabilmesi için simüle edilen deneyin ana özellikleri de özetlenmiş̧ir. Deneyde kullanılan serbest düşme düzeneği Şekil 7'de gösterilmektedir. Deneylerde, çelik serbest düşme ağılığının hızındaki değişimden yola çıkarak ve dinamik empedans analiz yönteminin reverberasyon uygulaması kullanılarak darbe yükleri belirlenmiştir [23]. Darbe ile ortaya çıkan dalga yansımaları Şekil 8'deki Lagrange diyagramı ile özetlenmektedir. Şekilde, beton numunede oluşan reverberasyon gösterilmiştir.

Deney düzeneğinin düşey alt sınırı, güçlü döşemeye sabitlendiği için ankastre kabul edilmiştir. Çelik serbest düşme ağırlı̆̆ının $\mathrm{x}$ ve $\mathrm{z}$ doğrultularındaki deplasmanı ve tüm eksenlerde dönmesi engellenmiştir. Benzer şekilde, deneylerde de çelik serbest düşme ağırlığı, yağlanmış düşey bir borunun içinde ilerlemektedir ve sadece y doğrultusunda hareket edebilmektedir. Tek eksenli darbe yüklemesi, modelde çelik ağırlığın y doğrultusundaki ilk hız şeklinde tanımlanmıştır. Modelde tanımlanan ilk hız, deneyler sırasında Doppler lazer hız ölçümü ile belirlenen ortalama çarpma hız olan $4.5 \mathrm{~m} / \mathrm{sn}$ 'dir. Beton numunenin alt ve üst yüzeylerine komşu olan çelik ağıllık ve alttaki çelik deney düzeneği ile oluşan (çelik-beton) kontaktlar tanjansiyel doğrultuda sürtünme katsayısı 0.30 olan yüzey-yüzey arası (surface-to-surface) kontakt olarak tanımlanmıştır. Boşluklu beton numunenin yükleme ile beton-beton kontaktı oluşturduğu dış yüzeyleri arasında tanjansiyel doğrultuda sürtünme katsayısı 0.50 olarak verilen öz-kontakt (self-contact), dik doğrultuda ise sert kontakt tanımlanmıştır. Sert kontakt, yüzeylerin birbirine penetre olmasının ve ayrıca çekme gerilmesi transferinin engellendiği kontakt tipi olarak tanımlanabilir. Modelde kullanılan sürtünme katsayıları, standardlar ve literatür referans alınarak belirlenmiştir [24-26].

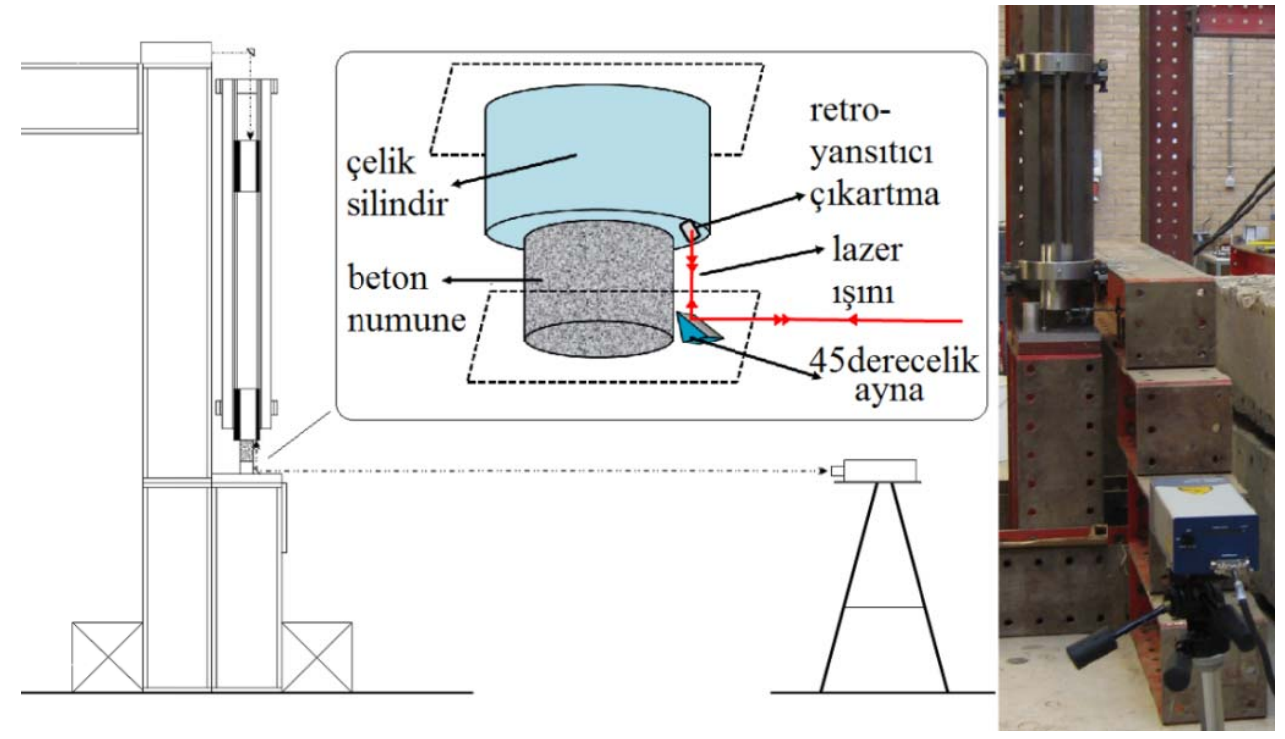

Şekil 7. Serbest düşme ve Doppler lazer hız ölçümü deney düzeneği 


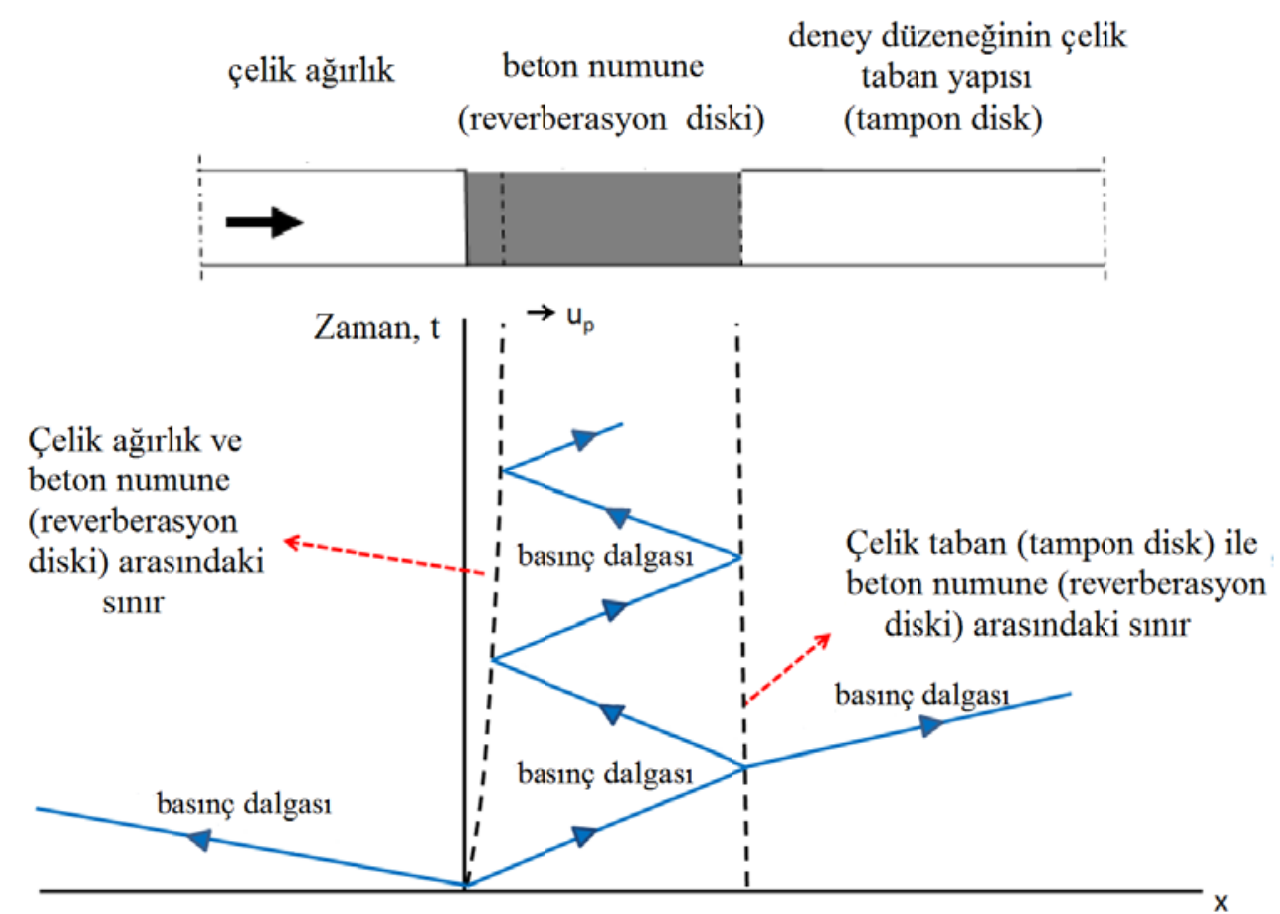

Şekil 8. Düşük dinamik empedanslı malzemenin (beton) iki daha yüksel dinamik empesanslı (çelik) malzeme arasında darbe davranışının Lagrange diyagramı

\section{SAYISAL BULGULAR}

Dinamik hesaplara geçmeden önce, boşluğun oluşturduğu gerilme konsantrasyonlarını gözlemleyebilmek için önce lineer elastik bir malzeme olan camda (Şekil 9) ve ardından da beton hasar plastisite modeli ile tanımlanmış sade beton plakada (Şekil 10) statik kapalı (static implicit) hesap gerçekleştirilmiştir. Boşluğun etkisi daha sonra tek bir boşluk içeren silindir numunenin dinamik davranışının açık dinamik hesap yöntemi ile incelenmesiyle araştırılmıştır.

Şekil 9 ve Şekil 10, Timoshenko ve Goodier tarafından kullanılan elastisite teorisi bazlı hesaplamalarda elde edilen gerilme konsantrasyonlarıyla karşılaştırıldı̆̆ında, cam ile yapılan hesaplamalarda malzemenin lineer elastik özellikleri nedeniyle denklem 2'den elde edilen gerilme konsantrasyon faktörleriyle (3 ve -1) tam bir uyum sağlandığını görülmektedir. Ancak beton üzerinde yapılan hesaplarda elastik sınırlar içinde konsantrasyon faktörleri uyum içindeyken Şekil 10 (sol), doğrusal olmayan davranışın başlamasıyla Şekil 10 (sağ) konsantrasyon faktörleri tamamen farklılaşmaktadır. Analizlerde, her iki malzemede de boşluğun altında oluşan çekme gerilmesi konsantrasyonları (basınç yüklemesinde) dikkati çekmektedir. Boşluklu malzemenin çatlak yapısının açılanmasında bu duruma tekrar değinilecektir. 

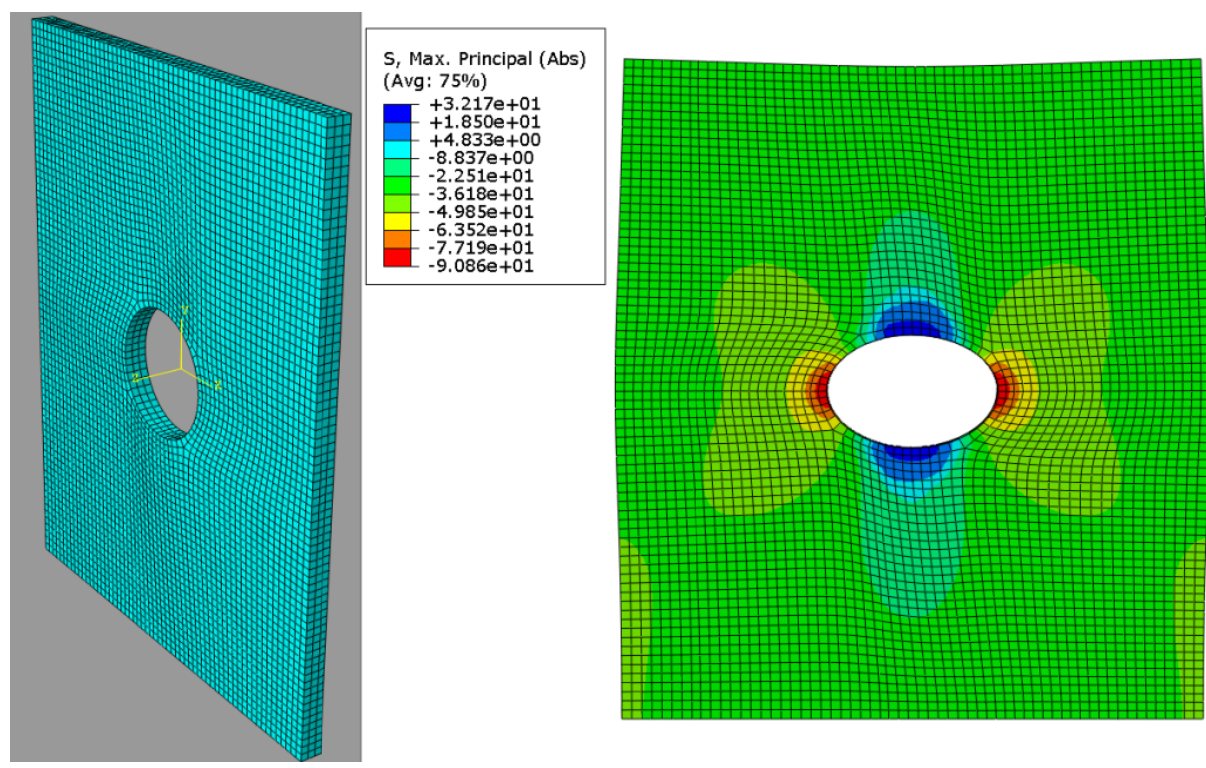

Sekil 9. Lineer elastik bir malzemede (cam) dairesel boșluk etrafinda oluşan gerilme konsantrasyonları (statik basınç altında)

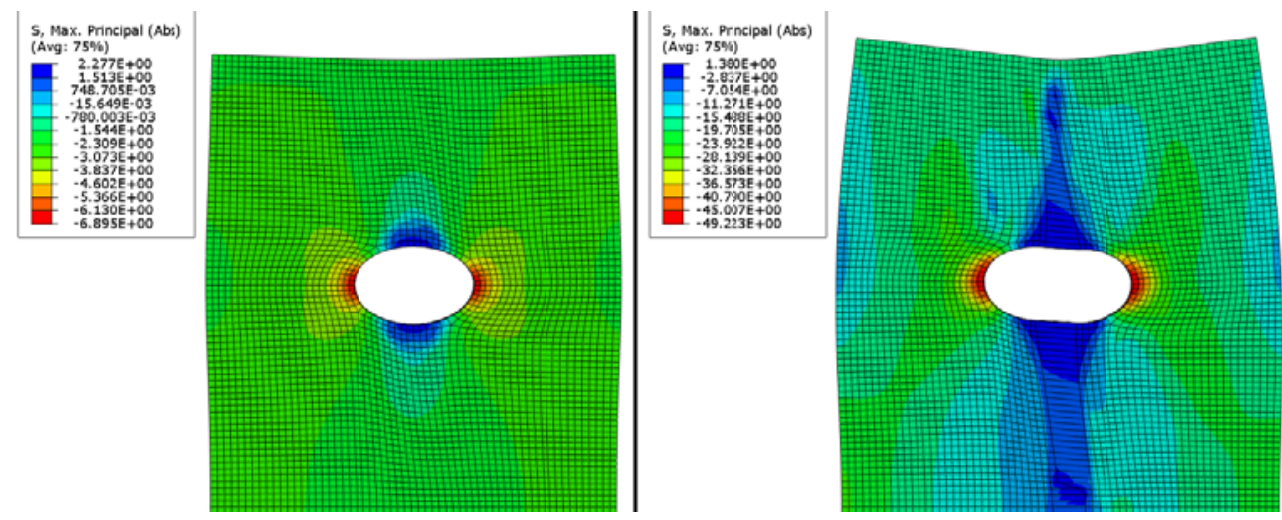

Şekil 10. Beton plakada dairesel boşluk etrafinda oluşan gerilme konsantrasyonları (statik basınç altında). Sol: elastik sinır içinde, Sağ: elastik sinırın ötesinde

Merkezinde tek bir boşluk içeren sade betonun darbe yükü altındaki davranışı incelendiğinde, boşluk etrafındaki gerilme ve hasar oluşumu dinamik yük altında da detaylı bir şekilde görülmektedir. Şekil 11'te, kullanılan sonlu eleman ağının genel görünümü ve maksimum (mutlak) asal gerilme dağılımı gösterilmektedir. Analizde, deneysel numune boyutları esas alınarak, numunenin yüksekliği $75 \mathrm{~mm}$ yarıçapı $30 \mathrm{~mm}$ alınmıştır. Şekilde, beton numuneye odaklanabilmek için, yüksekliği $220 \mathrm{~mm}$ olan çelik serbest düşme 
ağırlığının sadece bir kısmı görülmektedir. Şekil 11 'teki gerilme dağılımına bakıldığında, darbe yükü altında boşluğun alt ve üstünde oluşan çekme gerilmesi konsantrasyonu ve yanlarda oluşan basınç gerilmeleri yine açık bir şekilde görülmektedir.

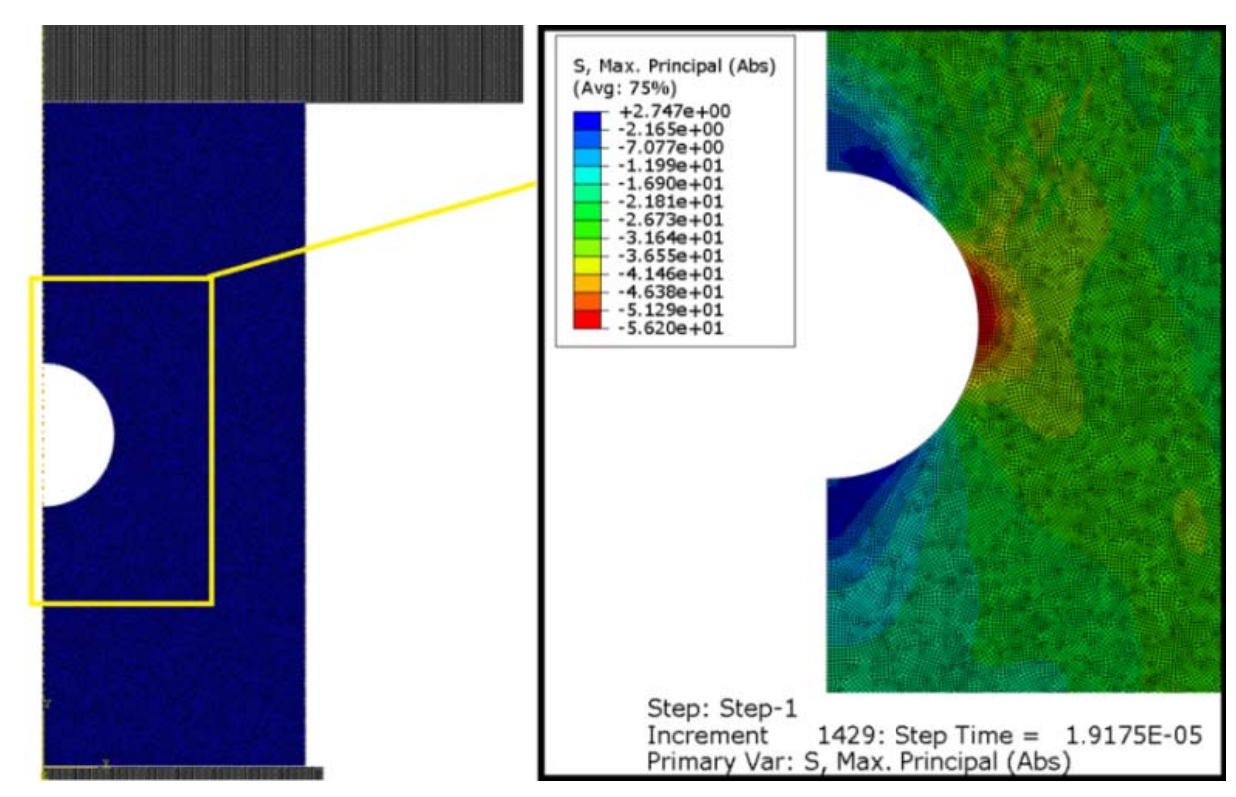

Şekil 11. Dairesel boşluk içeren beton silindirde darbe yükü altında oluşan çekme ve basinç gerilme konsantrasyonlart

Analizlerde çatlak oluşumu ve ilerlemesi, çekme ve basınç hasar değişkenlerinin (DamageC and DamageT) konturlarıyla gözlemlenmiştir. Hasar gelişiminden yola çıkarak elde edilen çatlak dağılımı, deneylerde elde edilen gerçek çatlak dağılımının gerçekçi bir tahminidir. Serbest düşmeli darbe deneyine maruz kalmış, dairesel boşluk içeren betonun çekme ve basınç hasar konturları iki değișik zaman için Şekil 12'te gösterilmiștir. Çimento bazlı malzemeler çekme ve basınç altında çok farklı davranışlar sergiledikleri için analizlerde basınç hasar parametresi çekme hasarından zamanlama olarak daha sonra gelişim göstermektedir. Şekil 11'te maksimum asal gerilme konturunun incelendiği zaman $\left(1.91 \times 10^{-5} \mathrm{sn}\right)$ için çekme ve basınç hasar konturları gözlemlendiğinde, çekme hasarının boşluğun alt ve üstünde odaklandığı Şekil 12 'te görülmektedir. Aynı zaman adımında, basınç hasarının ise çok düşük değerlerde olduğu görülmüştür. Basınç hasarı daha sonraki bir zamanda (örneğin yaklaşık $4.5 \times 10^{-5} \mathrm{sn}$ ), yine Şekil 12 'te görüldüğü gibi gözlemlenebilir değerlere ulaşmıştır. Basınç veya çekme gerilmeleri nedeniyle boşluğun etrafından başlayan çatlaklar daha sonra yapısal etkilerden özellikle sınır şartlarından da etkilenerek yönlerini belirlemektedirler. Beton numunenin alt yüzeyi ile çelik tabla ve numunenin üst yüzeyi ile çelik serbest düşme ağırlığı arasındaki sürtünmeler, çatlakların ilerlemesini ve eğimini etkilemektedirler. 
Boşluklu Betonun Darbe Yükü Altındaki Davranışının Mezoskopik Analizi
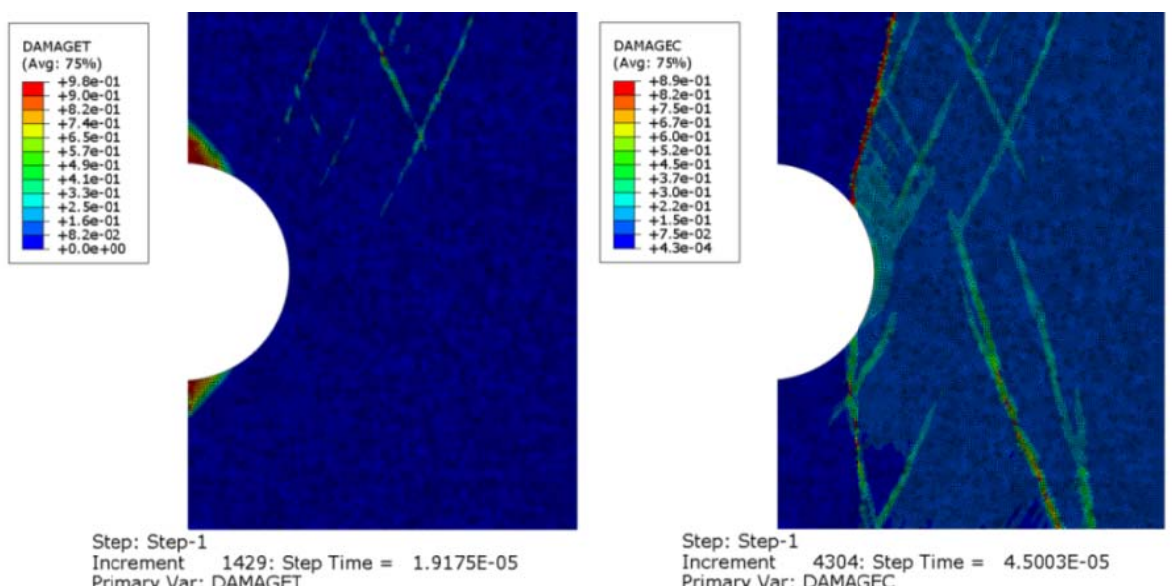

Şekil 12. Darbe yükü altında çekme ve basınç hasar dă̆glımı

Daha fazla sayıda düzgün dağılımda dairesel boşluk içeren beton model numuneler incelendiğinde, boşluk sayısı ve dağılımının etkisi açık bir şekilde görülmektedir. Şekil 13 'te de görüldüğü gibi, boşluk büyüklüğünün artması, (sabit toplam boşluk miktarı=0.10 için) darbe dayanımının azalmasına neden olmuştur. Bu etki deneysel numunelerden elde edilen sonuçlarda da görüşmüştür.

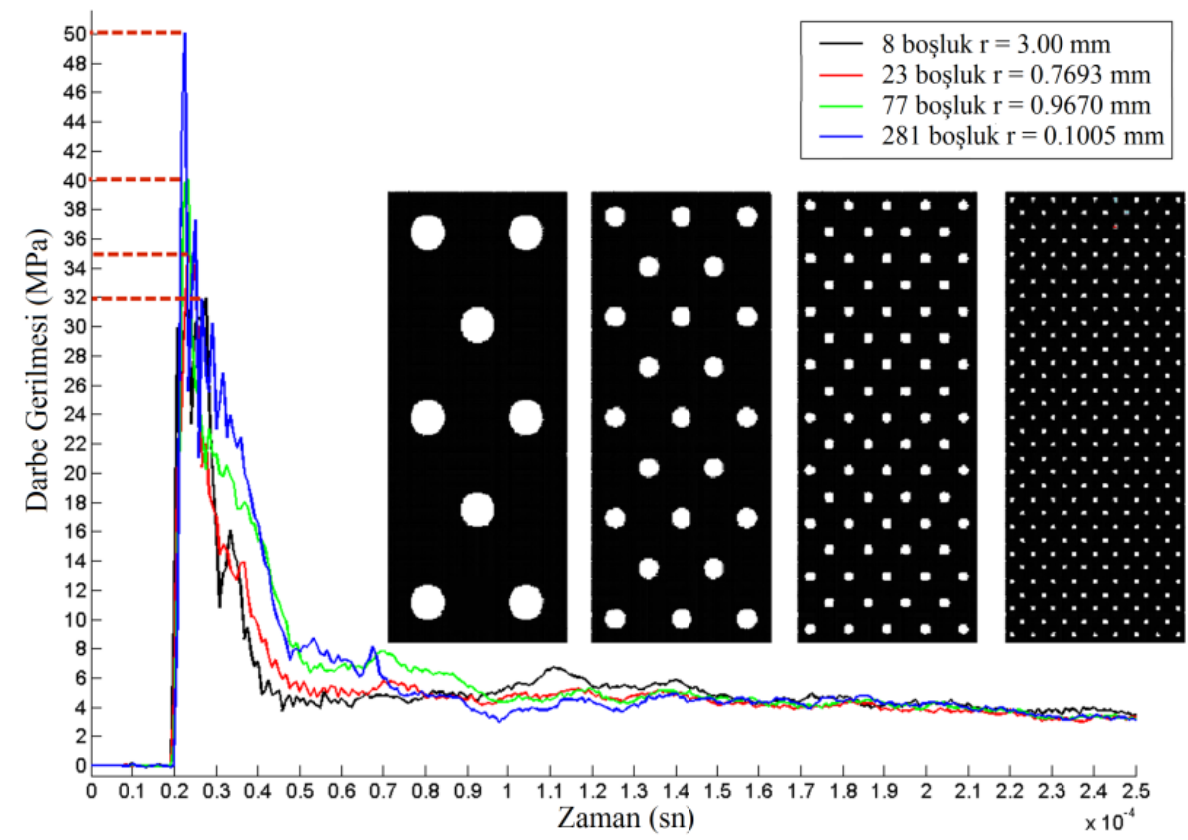

Şekil 13. Farklı boşluk boyutuna sahip model boşluklu betonların (0.10 sabit toplam boşluk) darbe gerilmesi zaman ĕgrileri 
Deneysel olarak da üretilmiş bir boşluklu ve bir dolu beton numune kapalı dinamik hesaplamalarla değerlendirilmiştir. Farklı tipte boşluklu betonlar üzerinde gerçekleştirilen deneylerde, agrega boyutu ve dolayısıyla oluşan boşluk boyutunun küçültülmesiyle malzemenin gerek statik, gerekse dinamik dayanımının arttı̆̆ 1 ve bunu yanında projenin temel amaçlarından biri olan daha küçük boyutta fragmanlara ayrılmanın da sağlandığı görülmüştür. $\mathrm{Bu}$ nedenle de nümerik sonuçları paylaşılmak üzere 2-4 $\mathrm{mm}$ bazalt agrega içeren sıkıştırılmış (dolayısıyla dayanımı artırılmış) boşluklu bir beton karışımı seçilmiştir. Dolu beton olarak ifade edilen numuneler ise, önce boşluklu beton şeklinde üretilip, hemen taze haldeyken priz gecikitirici katkının da etkisiyle işlenebilirliği yüksek çimento hamuru ile doldurulup vibrasyona tabi tutularak üretilmiştir. Bu nedenle dolu betonlar, normal betondan özellikle ince agrega içermemeleri nedeniyle farklıdırlar. Temel olarak mezo boyutta boşlukları çimento hamuru ile doldurulmuş boşluklu betonlardır. Bu betonlar, boşluklu betonlarla karşılaştırılıp boşlukların malzemenin gerilme davranışına ve çatlak dağılımına etkisini inceleyebilmek için üretilmişlerdir. Sayısal olarak incelenen karışımların bileşenleri Tablo 1'de özetlenmiştir. Analiz edilen boşluklu betonun dinamik ve statik dayanımları ve bazı özellikleri Tablo 2'de özetlenmektedir. Deneysel çalışmada boşluklu betonun dinamik basınç (darbe) dayanımı, dinamik empedans yönteminin reverberasyon uygulaması kullanılarak elde edilmiştir [23]. Dolu beton ise 61.1 MPa statik basınç dayanımına sahiptir ve mezo-boyutta boşluk miktarı sıfırdır.

Tablo 1. Boşluklu ve dolu betonun karışım içeriği

Karışım

\section{Bazalt Kırmataş}

(2-4 mm) (gr)

Bazalt Kırmataş

(2-4 mm) (gr)

Çimento

CEMI 42.5R (gr)

$\mathrm{Su}(\mathrm{gr})$

Akışkanlaştırıcı

(gr)

Priz geciktirici katk1

(gr)
PRC1

\section{$\mathrm{FC} 1$}

(Boşluklu beton şeklinde üretilip, boşlukları çimento hamuru ile doldurulmuş beton)

(numuneler tekil olarak üretilmiş ve sıkıştırılmıştır.

Bu nedenle karışımdaki kütleler gr ile gösterilmektedir.)

$$
2000
$$

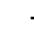

\section{0}

351

951

105

285

0.97

1.20 
Boşluklu Betonun Darbe Yükü Altındaki Davranışının Mezoskopik Analizi

Tablo 2. Analiz edilen boşluklu betonun deneysel özellikleri

$\begin{array}{cccccc}\begin{array}{c}\text { Numune } \\ \text { kodu }\end{array} & \begin{array}{c}\text { Darbe hızı } \\ (\mathrm{m} / \mathrm{sec})\end{array} & \begin{array}{c}\text { Darbe } \\ \text { dayanımı } \\ (\mathrm{MPa})\end{array} & \begin{array}{c}\text { Mezo- } \\ \text { boyutta } \\ \text { boşluk } \\ (\%)\end{array} & \begin{array}{c}\text { Ortalama } \\ \text { darbe } \\ \text { dayanımı } \\ (\mathrm{MPa})\end{array} & \begin{array}{c}\text { Ortalama } \\ \text { statik } \\ \text { basıç } \\ \text { dayanımı } \\ (\mathrm{MPa})\end{array} \\ \text { PRC1_1 } & 4.34 & 73.30 & & & \\ \text { PRC1_2 } & 4.50 & 79.59 & & & 41.89 \\ \text { PRC1_3 } & 4.52 & 75.86 & 20.33 & 76.78 & \\ \text { PRC1_4 } & 4.47 & 76.09 & & & \\ \text { PRC1_5 } & 4.53 & 79.05 & & & \end{array}$

Boşluklu beton ve dolu beton numunelerin sonlu eleman analizi ile (açık direkt entegrasyon yöntemi kullanılarak) elde edilen darbe gerilmesi-zaman eğrileri sırasıyla Şekil 14 and Şekil 15'de verilmiştir.

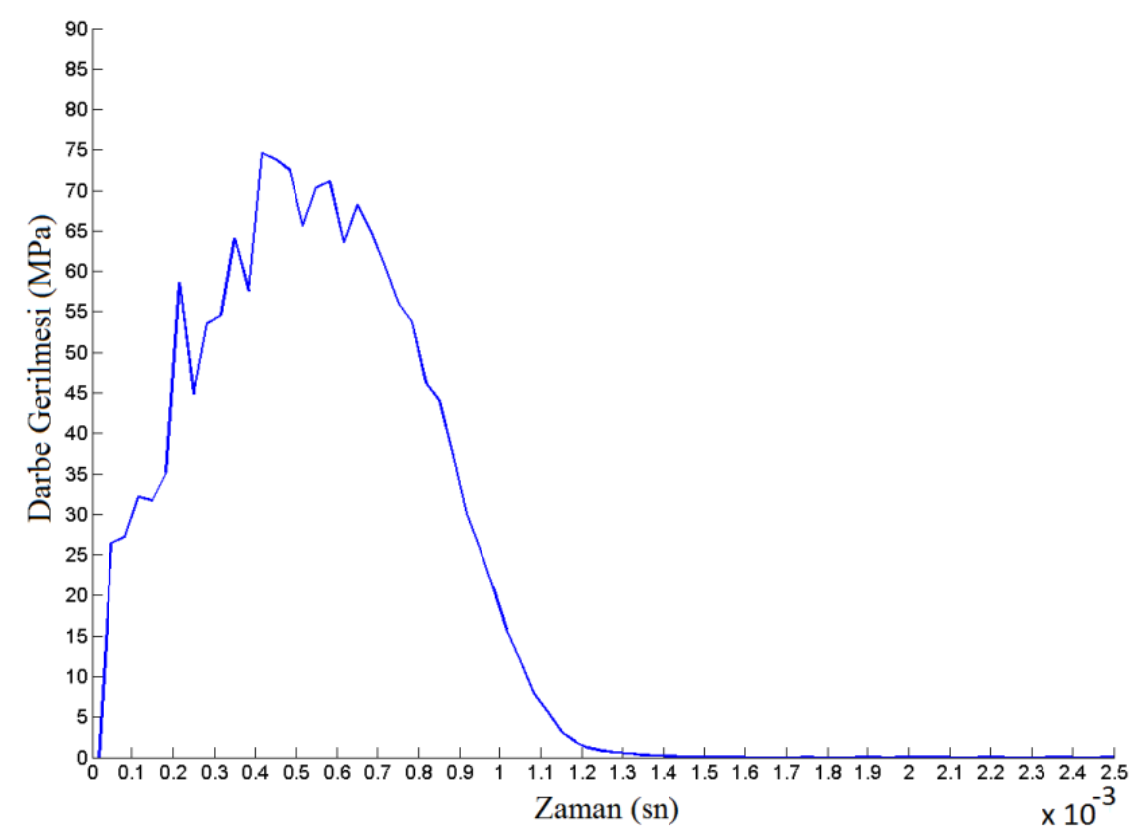

Şekil 14. 2-4 mm kirma bazalt agrega içeren boşluklu betonun (PRC1) sonlu eleman analizi ile elde edilen darbe gerilmesi zaman eğrisi 


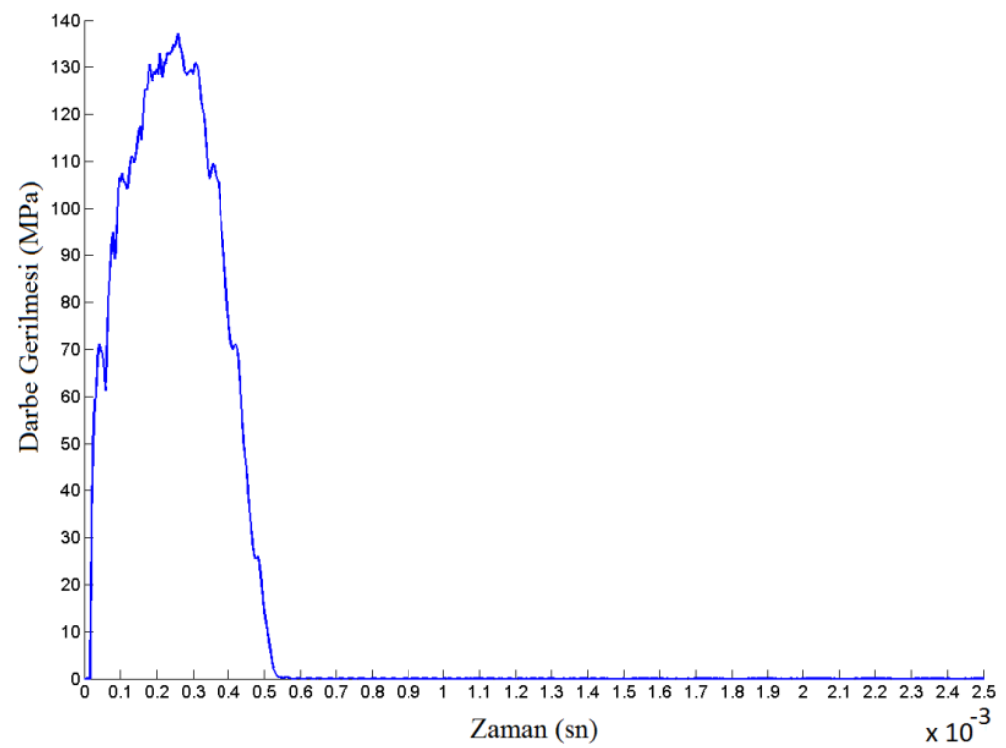

Şekil 15. Dolu betonun (FC1) sonlu eleman analizi ile elde edilen darbe gerilmesi zaman ĕgrisi

Dolu betonların sonlu eleman analizinde, darbe dayanımında görülen ve beklenen artışın yanında, boşluklu betona kıyasla dalganın daha hızlı ilerlemesiyle tepe yüküne daha çabuk ulaşılmakta, eğrinin kuyruk bölümü Şekil 15 'de olduğu gibi çok daha kısa olmaktadır. Şekil 16 'da, $1.5 \times 10^{-3}$ sn için çekme ve basınç hasar parametresi dağılımları ayrı ayrı gösterilmektedir. Şekillerde, basınç ve çekme hasar değerleri 0.90 'dan yüksek olan elemanlar şekilden kaldırılarak çekme ve basınç çatlak gelişimleri daha açık bir şekilde belirtilmektedir. Şekil 16'nın en son figüründe ise çekme veya basınç parametrelerinden herhangi biri 0.9 'a ulaştığında elemanın kaldırıldığı durum gösterilmiştir. Bu son gösterim gerçeğe yakın bir çatlak dağılımı resmi ortaya koymaktadır. Verilen şekiller için belirtilmelidir ki gösterilen konturlar (üst kısımda bulunan odaklanılmış imajlarda görüldüğü gibi) değerlerine göre değişik renkler almaktadırlar ancak sonlu eleman ağı çok ince olduğundan tüm numuneye bakıldığında siyah renkte görülmekte, 0.9 'dan büyük olması nedeniyle kaldırılan elemanlar da beyaz renkte bulunmaktadır. Hasar parametrelerinin dolu betondaki gelişimi (çekme veya basınç hasar parametrelerinden herhangi birinin $0.9^{\prime}$ dan büyük olması durumunda kaldırılması ile) Şekil 19'da görülmektedir. Araştırma projesinin önemli bir amacı fragmantasyon davranışının belirlenmesi olduğu için, hasar analiz sonuçları incelenirken darbe etkisinin tamamlandığ ve kalıcı hasarın gerçekleştiği zaman aralıklarına odaklanılmıştır. Kontur şekilleri incelendiğinde, boşluklu betonda çoklu çatlakların oluştuğu ve dolayısıyla da numenin darbe yükü altında hedeflendiği gibi çok sayıda parçaya ayrıldığı gözlemlenmektedir.

Analizlerden elde edilen darbe yükü altında gelişen çatlak dağılımının (Şekil 16 ve Şekil 17), deney sırasında gerçekleştirilen hızlı kamera görüntüleriyle (Şekil 18) ve bilgisayarlı tomografi imajlarıyla da yakın oldukları gözlemlenmiştir. 

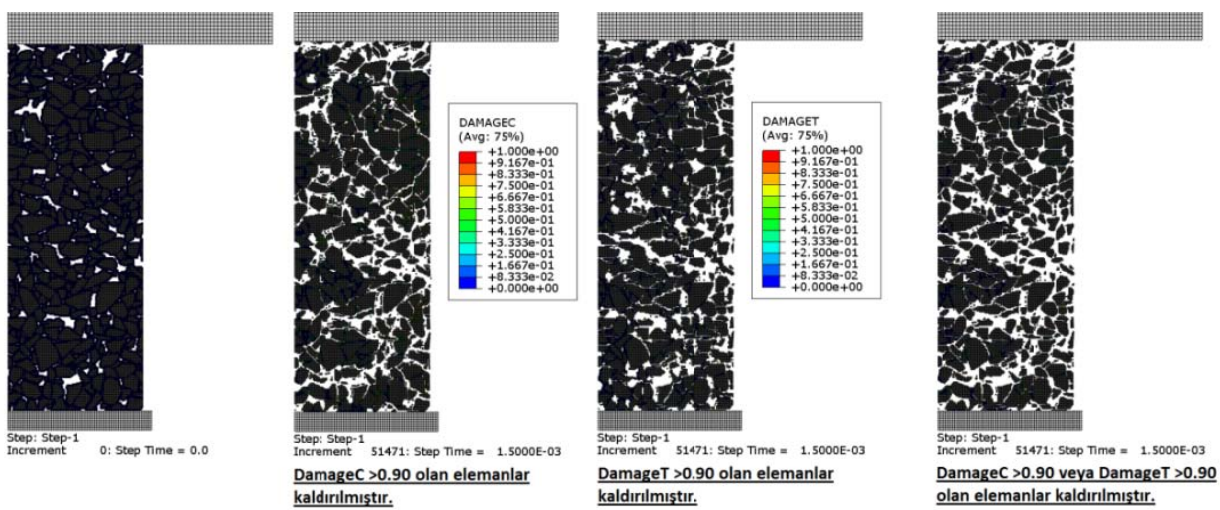

Şekil 16. 2-4 mm bazalt agrega içeren boşluklu betonun basınç ve çekme hasar konturları ile gösterilen çatlak dă̆llımları
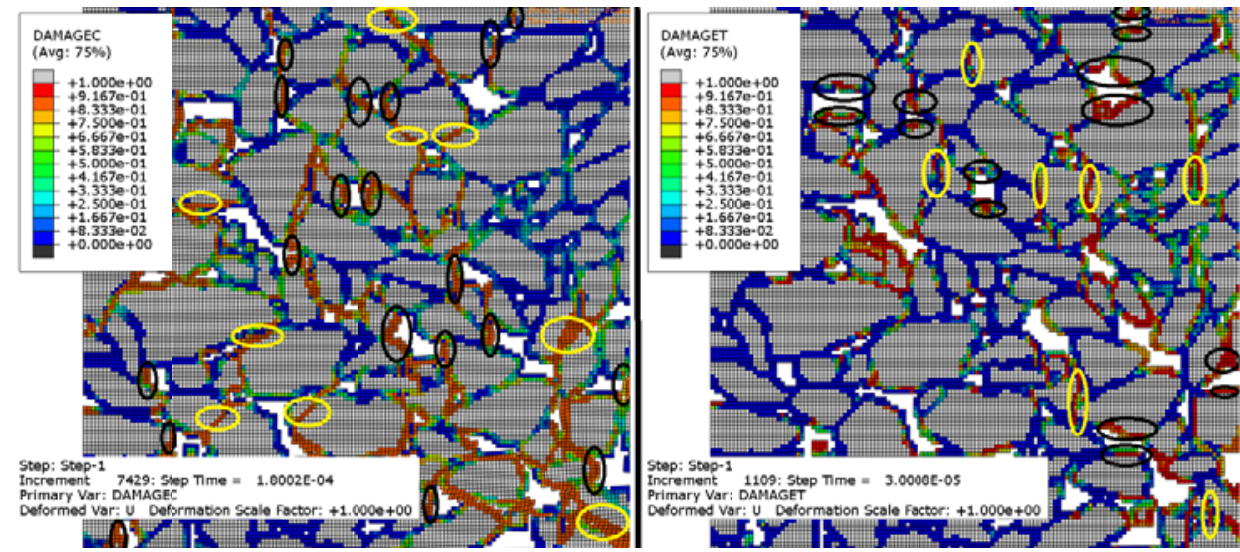

Şekil 17. 2-4 mm bazalt agrega içeren boşluklu betonun basınç ve çekme hasar konturları

Boşluklu betonda çatlaklar normal betonda olduğu gibi agrega-çimento hamuru arafazından başlayabilmektedir. Ancak normal betondan farklı olarak boşluklu betonda çok yüksek miktarda mezo-boyutta boşluklar bulunmaktadır ve betonu oluşturan iri agregalari ince çimento hamuru köprüleri bir arada tutmaktadır. Bu nedenle boşluklu betonda çatlaklar, varolan fazların dağılımının da etkisiyle gelişim göstermektedir. Boşluğun alt ve üst bölgelerinde, daha önce de vurgulanmış olan çekme gerilmesi konsantrasyonları geliştiği için pek çok çatlak, bu lokasyonlardan da başlayabilmektedir. Sonuç olarak ise çok sayıda ince çimento hamuru köprülerinden kırılan beton, çoklu çatlaklar ve küçük boyutta fragmanlar oluşturmaktadır. Agregaların üst ve alt bölgelerinde bulunan üç eksenli gerilme ile korunmuş kısımlar deneylerde numune tamamen çatladıktan sonra da sağlam kalmış, agegaların üst ve altında küçük boyutta koniler oluşturmuşlardır. Bu durum Şekil 18'de de görülmektedir. Şekil 17'de de agregaların alt ve üst kısımlarındaki çimento bazlı fazların hasar değerlerinin düşüklüğü görülebilmektedir. Yüklemenin özelliğinden ve betonun çekme dayanımının basınç dayanımından çok düşük olmasından kaynaklanan yükleme 
doğrultusuna paralel çekme çatlakları da her iki şekilde de gözlemlenebilmektedir. Dolu betonun Şekil 19'da görülen hasar parametresi dağılımı, mezo-boyutta boşluklar olmaması durumunda, hedeflenen çoktu çatlak yapısının oluşmadığını göstermektedir. Bu durum dolu betonların deneysel analizinde de gözlemlenmiştir. Çatlak dağılımının sınır şartlarından, özellikle de beton numunenin çelik ile oluşturduğu sınırlarda oluşan sürtünmeden etkilenmesi söz konusu olsa bile, dolu ve boşluklu betonlar arasındaki bu temel kırılma davranışı farkı açık bir şekilde gözlemlenebilmektedir.

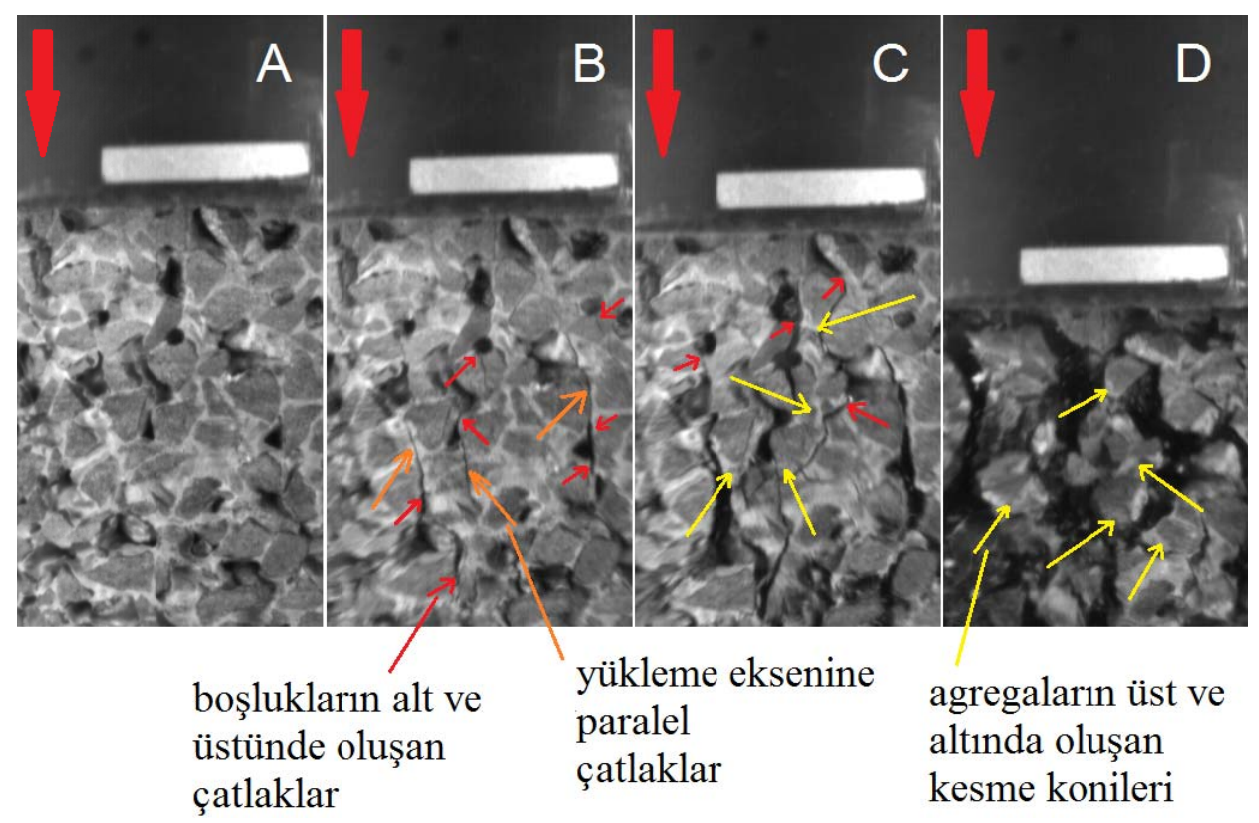

Şekil 18. Boşluklu betonun darbe deneyinin hızlı kamera çekimlerinden seçilmiş imajlar
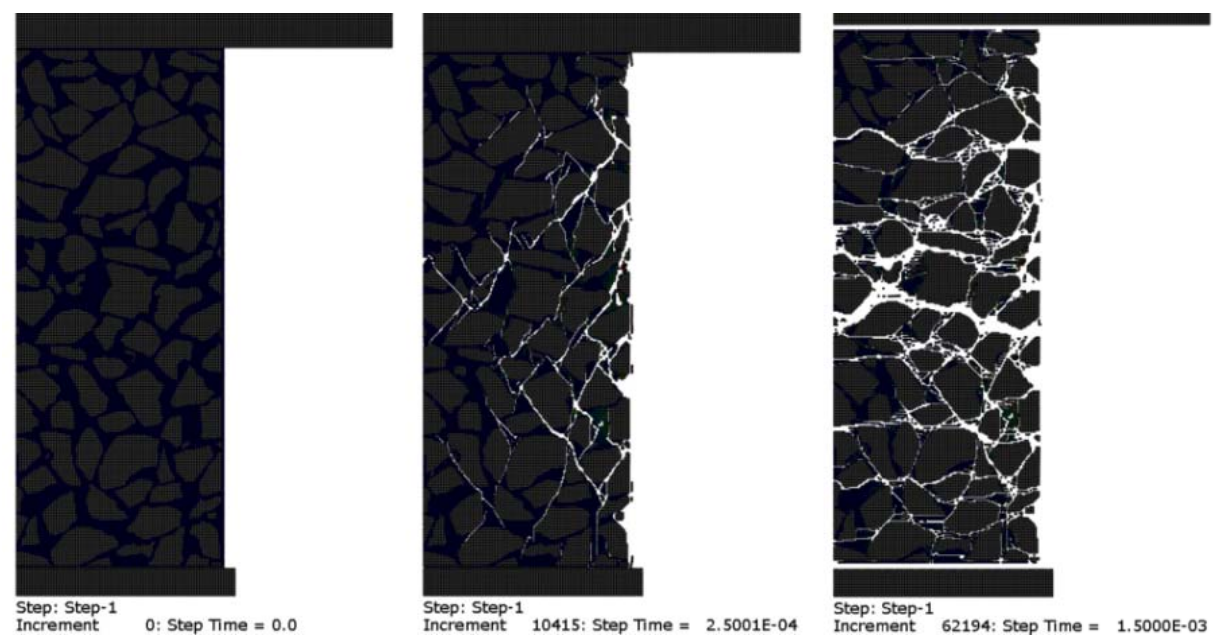

Şekil 19. Dolu betonun çekme+basınç hasar konturları ile gösterilen çatlak dağılımları 
Boşluklu Betonun Darbe Yükü Altındaki Davranışııın Mezoskopik Analizi

\section{SONUÇLAR}

Boşluklu betonun dört-fazlı (agrega, arafaz, çimento hamuru ve havadan oluşan) bir malzeme, olarak temsil edildiği seçilmiş mezoskopik analiz sonuçlarının sunulduğu bu çalışmanın başlıca sonuçları aşağıdaki gibi özetlenebilir:

- Rastgele dağılımlı ve şekilli boşluklar içeren deneysel boşluklu beton karışımlarının sonlu eleman analizlerinde gerçeğe yakın bir şekilde temsil edilebilmesi, geliştirilen sonlu eleman ağı oluşturma programı ile mümkün olmuştur.

- Açı zaman entegrasyonu hesapları, dinamik yükleme süresinin çok kısa olduğu ve karmaşık kontakt durumlarının yer aldığı serbest düşmeli darbe deneyinin analizinde verimli olarak gerçekleştirilmiştir.

- Malzemenin darbe deneyindeki davranışının incelenmesinde, Beton Hasar Plastisite Modeli, çimento bazlı fazların (arafaz ve çimento hamuru) gerçeğe yakın bir şekilde tanımlanmasını sağlamıştır.

- Boşluklu betonda, deneylerde de olduğu gibi dinamik yükleme altında çoklu çatlaklar oluşmaktadır. Bu durum mezo-boyutta boşluk içermeyen dolu betonlar için geçerli değildir.

- Simulasyon sonuçları, hem darbe dayanımının hem de oluşan çatlak dağılımın tahmininde deneysel sonuçlarla uyum göstermektedir.

\section{Teşekkür}

Bu araştırma projesi, Delft Teknoloji Üniversitesi'nde gerçekleştirilmiş, Hollanda Savunma Akademisi tarafından desteklenmiştir.

\section{Kaynaklar}

[1] Yang J and Jiang G., Experimental study on properties of pervious concrete, Cement and Concrete Research, 33 (3), 381-386, 2003.

[2] Marolf A, Neithalath N, Sell E, Wegner K, Weiss J, Olek J., Influence of aggregate size and gradation on the acoustic absorption of enhanced porosity concrete, ACI Materials Journal, 101(1), 82-91, 2004.

[3] Lubliner, J.J., Oliver, S.O. and Oñate, E., A plastic-damage model for concrete, International Journal of Solids and Structures, 25(3), 229-326, 1989.

[4] Lee, J. and Fenves, G.L., A plastic damage model for cyclic loading of concrete structures, Journal of Engineering Mechanics, ASCE, 124, 892-900, 1998.

[5] Chaudhari S.V. and Chakrabarti, M.A., Modeling of concrete for nonlinear analysis using finite element code ABAQUS, International Journal of Computer Applications, 44(7), 14-18, 2012. 
[6] Jankowiak, T. and Lodygowski, T., Identification of parameters of concrete damage plasticity constitutive model, Foundations of Civil and Environmental Engineering, 6, 53-69, 2005.

[7] ABAQUS Analysis User's Manual, Simulia, 2013.

[8] Kmiecik, P. and Kaminski M., Modelling of reinforced concrete structures and composite structures with concrete strength degradation taken into consideration, Archives of Civil \& Mechanical Engineering, 11(3), 623-636, 2011.

[9] Timoshenko, S and Goodier, J.N., Theory of Elasticity, Prentice-Hall, 2001.

[10] Green, D.J., An Introduction to the Mechanical Properties of Ceramics, Cambridge University Press, 1998

[11] Agar Ozbek A.S., Weerheijm J., Schlangen E., van Breugel K., Investigating porous concrete with improved strength: Testing at different scales, Construction and Building Materials 41, 480-490, 2013.

[12] Noh G. and Bathe K. J., An explicit time integration scheme for the analysis of wave propagations, Computers and Structures, 129, 178-193, 2013.

[13] Farooq, U. and Gregory K., Explicit dynamic simulation of drop-weight low velocity impact on carbon fibrous composite panels, ARPN Journal of Engineering and Applied Sciences, 5(3), 50-61, 2010.

[14] Huang, C.C. and Wu, T.Y., A Study on Dynamic Impact of Vertical Concrete Cask Tip-over Using Explicit Finite Element Analysis Procedures, Annals of Nuclear Energy 36(2), , 213-221, 2009.

[15] Elmer,W. VII, Taciroglu, E. and McMichael, L., Dynamic Strength Increase of Plain Concrete From High Strain Rate Plasticity with Shear Dilation, International Journal of Impact Engineering, 45, 1-15, 2012.

[16] Chopra, A.K., Dynamics of Structures: Theory and Applications to Earthquake Engineering, Prentice Hall, 2000.

[17] Huebner, K.H., Dewhirst, D.L., Smith, D.H. and Byrom T.G., The Finite Element Method for Engineers, Wiley, 2001

[18] Chen, Z., Shin, M. and Adrawes, B., Numerical simulation and parametric study of prestressed concrete crosstie and fastening system, PCI/NBC, September 29- October 2, Nashville, USA, 2012.

[19] Sun, J. S., Lee, K. H. and Lee, P. H., Comparison of implicit and explicit finite element methods for dynamic problems, Journal of Materials Processing Technology, 105(1-2), 110-118, 2000.

[20] Noels, L., Stainier, L. and Ponthot, J.P., Combined implicit/explicit time-integration algorithms for the numerical simulation of sheet metal forming, Journal of Computational and Applied Mathematics, 168(1-2), 331-339, 2004.

[21] Dhanasekar, M. and Haider, W., Explicit finite element analysis of lightly reinforced masonry shear walls, Computers and Structures, 86(1-2), 15-26, 2008. 
Boşluklu Betonun Darbe Yükü Altındaki Davranışııın Mezoskopik Analizi

[22] Siad L., Ouali M. O. and Benabbes A., Comparison of explicit and implicit finite element simulations of void growth and coalescence in porous ductile materials, Materials and Design, 29(2), 319-329, 2008.

[23] Agar Ozbek A.S., Weerheijm J., Schlangen E., van Breugel K., Drop weight impact strength measurement method for porous concrete using laser Doppler velocimetry, Journal of Materials in Civil Engineering, 24(10), 1328-1336, 2012.

[24] Deutsches Institut für Normung, Falsework calculation, design and construction DIN 4421:1982, Beuth Veriag GmbH, Berlin, Almanya, 1982

[25] British Standards Institution, Falsework performance requirements and general design, Draft prEN 12812, Londra İngiltere, 1997.

[26] Gorst, N.J.S., Williamson, S.J., Pallett, P.F. and Clark, L.A., Friction in temporary works, Research Report, University of Birmingham, U.K, 2003. 